\title{
As vias de negação da vontade em Schopenhauer
}

\author{
The ways of denial of the will in Schopenhauer
}

\author{
Lívia Ribeiro \\ Mestre em Filosofia pela Universidade Federal Rural do Rio de Janeiro (UFRRJ) \\ E-mail: liviaribeiro862@yahoo.com.br
}

Resumo: Neste artigo analiso como se dá a transição da afirmação para a negação da vontade em suas duas vias, a do conhecimento e apropriação do sofrimento alheio e a do sofrimento radicalmente sentido. Para isso, exponho os atos compassivos como meios de fomentar a negação e questiono se há um tipo de caráter que favoreça o surgimento da negação pela primeira via, enquanto a segunda via torna possível a negação da vontade independente do caráter que o indivíduo expressava antes dessa experiência.

Palavras-chave: Negação da vontade; Compaixão; Sofrimento.
Abstract: In this paper I analyze how is the transition from affirmation to the negation of the will in its two-way, the knowledge and appropriation of other people's suffering and the suffering radically sense. For this, I expose the compassionate acts as means of promoting the denial and I question whether there is a type of character that favors the emergence of the denial by the first route, while the second route makes possible the denial independent of the character individual expressed before that experience.

Keywords: Denial of the will; Compassion; Suffering. 


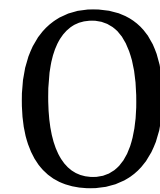

homem, enquanto ser volitivo, vive constantemente agitado pelo movimento do querer sem fim, atormentado pela incessante busca por coisas que não podem lhe proporcionar uma satisfação definitiva e são pontos de partida para novos desejos. Ao afirmar a vontade, o indivíduo confirma sua participação no ciclo eterno do querer, se dispõe a permanecer no contínuo desejar e buscar satisfação. Para Schopenhauer, "a vida, via de regra, nada mais é do que uma série de esperanças mal-sucedidas, tentativas fracassadas e equívocos reconhecidos tardiamente"1 e só pode ser redimida por meio da negação da vontade de vida (Verneinung des Willens zum Leben). Somente na negação da vontade o sujeito pode tornar-se indiferente ao que antes o impelia a agir, desfrutando de "uma paz inabalável, uma profunda calma e jovialidade interior"2.

Segundo o filósofo, os indivíduos agem seguindo uma relação necessária entre motivo e caráter. Existem três caracteres e motivações fundamentais: egoísmo, maldade e compaixão ${ }^{3}$. Cada indivíduo reage aos motivos que se apresentam de acordo com seu caráter, que é inato e imutável. 0 ultrapassador do mundo é o maior e mais significativo acontecimento que pode ser exibido, pois somente nele entra em cena a liberdade, ou seja, a relação necessária entre motivos e caráter é suprimida. Schopenhauer afirma que a liberdade pertence à vontade como coisa-em-si e não ao seu fenômeno. Somente em sua negação, a vontade que se manifesta no corpo pode entrar em contradição consigo mesma, negando o que o fenômeno expressa. No estado de negação da vontade os motivos não podem mais fazer efeito, pois o caráter e tudo o que é individual desaparece.

A negação da vontade pode se dar por dois caminhos: por um primeiro, definido pelo conhecimento do sofrimento inerente à existência e percepção da unidade de todos os seres; ou por um segundo caminho, que se torna possível quando o indivíduo experimenta um sofrimento intenso, capaz de tornar a vontade repugnante. Adiante, veremos como, segundo o pensamento schopenhaueriano, ocorreria a transição da afirmação para a negação por cada uma dessas vias.

\section{Visão que transpassa o princípio de individuação}

\footnotetext{
1 SCHOPENHAUER, A. P/P, § $172 a$, p. 184.

2 SCHOPENHAUER, A. WWV I/MVR I, § 68, p. 494.

3 Cf. SCHOPENHAUER, A. M/M, § 20, p.195.

As vias de negação da vontade em Schopenhauer
} 
O princípio de individuação é o modo pelo qual nosso conhecimento é elaborado. Como sabemos, esse princípio é constituído por espaço e tempo. Sob o princípio de individuação a vontade una, indivisível e atemporal aparece em coisas múltiplas e diversas. Schopenhauer faz referência à tradição védica ao empregar o termo véu de maia [Schleier der Maja] para designar o mundo fenomênico, "encoberto" pelas formas do nosso modo de conhecer, que faz com o que uno apareça na multiplicidade. Enquanto seu modo de conhecimento está vinculado a esse princípio, o indivíduo se vê como algo distinto de todo o resto do mundo. Por não enxergar os outros seres como dotados da mesma essência, e sim meros fantasmas, cada um visa ao próprio bem sem se importar com o quanto pode afetar outros corpos. Uma visão clara do mundo só poderia ocorrer se conseguíssemos enxergar fora do nosso modo ordinário de conhecimento direcionado para as coisas particulares e atingíssemos o universal. Essa visão é a condição necessária para que o indivíduo alcance o conhecimento da essência do mundo.

Apesar de extraordinário, é possível um tipo de conhecimento que não se submete a tal princípio. Schopenhauer apresenta a visão que transpassa o princípio de individuação como algo que pode ocorrer subitamente, sem qualquer deliberação do sujeito, e que proporciona um conhecimento que vai além dos fenômenos e atinge o que há de essencial no mundo. 0 conhecimento que transpassa esse princípio é imediato e intuitivo, não pode ser comunicado por meio de conceitos, não pode ser adquirido ou eliminado pelo raciocínio. Existem graus diversos dessa intuição e cada um pode levar o sujeito a uma experiência distinta. No âmbito estético, é possível a contemplação das Ideias, que são objetidades da vontade, formas gerais das quais os objetos são cópias, condição em que não se verifica ainda a objetivação fenomênica4; no ético, surge o fenômeno da compaixão, em que um grau mais baixo da visão que transpassa o princípio de individuação proporciona a justiça espontânea e de um grau mais elevado surge a caridade desinteressada; com a supressão do conhecimento submetido ao princípio de individuação, pode surgir a negação da vontade.

\footnotetext{
${ }^{4}$ Schopenhauer afirma, no $\S 36$ de MVR I, que a arte é o modo de conhecimento que considera unicamente as Ideias, "que são a objetidade imediata e adequada da coisa-em-si. Ela [a arte] repete as Ideias eternas apreendidas por pura contemplação, o essencial e permanente dos fenômenos do mundo, que, conforme o estofo em que é repetido, expõe-se como arte plástica, poesia ou música. Sua única origem é o conhecimento das Ideias, seu único fim é a comunicação deste conhecimento" (SCHOPENHAUER, A. WWV I/MVR I, § 36, p. 253). 


\section{Compaixão}

O fenômeno da compaixão resultaria da visão exposta acima, intuição que permite o reconhecimento da mesma essência em outros fenômenos. Na fórmula védica Tat twam asi (Isso és tu), Schopenhauer identifica a melhor expressão do reconhecimento da identidade de todos os seres e afirma que "quem consegue enunciar tal fórmula para si mesmo com claro conhecimento e firme convicção íntima, referindose a cada ser com o qual entra em contato, decerto assegura-se de toda virtude e bemaventurança e se encontra no caminho reto da redenção" ${ }^{5}$. Quando o sujeito se percebe como parte de uma totalidade, e não mais como indivíduo isolado, seu próprio bem-estar fica em segundo plano e passa a considerar os outros, daí advêm um empecilho para a injustiça ou até mesmo ações que visam o alívio do sofrimento dos demais. Não há mais espaço para egoísmo e maldade no sujeito desvencilhado do princípio de individuação, pois a ilusão que o fazia se sentir diferente dos demais foi suprimida e a necessidade do outro lhe impele a agir. Justiça e caridade são provas de que o princípio de individuação já foi transpassado em determinados graus e o oposto, injustiça, maldade e crueldade, mostram que o indivíduo ainda está preso à ilusão da individuação.

Schopenhauer apresenta a justiça voluntária como a primeira virtude cardinal. A justiça possui um caráter negativo, é uma não-ação, a negação da injustiça. A injustiça consiste na afirmação da própria vontade com a invasão da esfera da vontade alheia e é esse o modo ordinário de manifestação da vontade. Ela se dá quando um indivíduo fere, destrói ou quando utiliza as forças de outrem para servir à sua vontade, ou seja, quando há afirmação para além do próprio corpo com negação da vontade alheia. É a afirmação da vontade do agente com consequente negação da vontade daquele que sofre o dano. "O conceito de injustiça é originário e positivo, já o oposto dele, o de justiça, é derivado e negativo"6. Em oposição ao modo ordinário de manifestação da vontade está o justo, aquele que não invade os limites de outrem para afirmar sua vontade, que não tenta aumentar seu bem-estar quando isso pode causar o sofrimento alheio. 0 homem justo se recusa a agir de um modo que inflige o direito e a propriedade de outrem. Segundo Schopenhauer,

${ }^{5}$ SCHOPENHAUER, A. WWV I/MVR I, § 66, p. 476.

${ }^{6}$ Idem, § 62, p. 434.

As vias de negação da vontade em Schopenhauer 
Quem reconhece e aceita voluntariamente o limite moral entre o injusto e o justo, mesmo ali onde o Estado ou outro poder não se imponha, quem, consequentemente, de acordo com a nossa explanação, jamais, na afirmação da própria vontade, vai até a negação da vontade que se expõe em outro indivíduo - é JUSTO. Portanto, não infligirá sofrimento a outrem para aumentar o próprio bem-estar, vale dizer, não cometerá crimes, e respeitará o direito e a propriedade alheios [...] pelo seu modo de ação, o homem justo mostra que RECONHECE sua essência, a Vontade de vida como coisa-em-si, também no fenômeno do outro dado como mera representação, portanto reencontra a si mesmo nesse fenômeno em certo grau, ou seja, desiste de praticar a injustiça, isto é, não inflige injúrias. Exatamente neste grau vê através do Véu de Maia e iguala a si o ser que lhe é exterior, sem injuriá-lo.

A justiça surge espontaneamente quando se deixa de considerar o abismo existente entre cada indivíduo, quando a diferença entre eu e não-eu é suprimida. Ela independe de imposições externas, nasce da percepção do sofrimento alheio e da possibilidade de causar danos aos outros, caso a vontade do agente seja afirmada. Para evitar o aumento do sofrimento dos outros indivíduos, o justo deixa de atender aos seus desejos e absorve o sofrimento que advém por contrariar o próprio querer. Schopenhauer afirma que quem professa incondicionalmente a justiça toma para si uma tarefa muito pesada e se dispõe a fazer sacrifícios que retiram da vida a doçura que poderia torná-la agradável e, dessa forma, pode levar o justo à resignação ${ }^{8}$.

A justiça se torna assim um meio para promover a negação da Vontade de viver, uma vez que a necessidade e o sofrimento, as condições próprias à vida humana, são a sua consequência; elas, porém, conduzem à resignação. Caritas, a virtude da filantropia, que vai mais longe, certamente leva ainda mais rapidamente ao mesmo resultado?

A verdadeira justiça custa sacrifícios a quem a pratica, pois é necessário que o sujeito se prive de afirmar sua vontade para evitar que essa afirmação acabe por negar a vontade de outra pessoa. A caridade vai além: o caridoso não apenas deixa de agir para evitar que sua ação seja a causa do sofrimento alheio, mas, ao ver a necessidade do outro, age para diminuir seu sofrimento. Ele não se priva apenas de ampliar seus bens tomando o que é do outro, mas abre mão do que já possui para doar a quem necessita. A caridade induz uma ação. Não se limita a deixar de agir para não prejudicar outro

${ }^{7}$ SCHOPENHAUER, A. WWV I/MVR I, § 66, p. 471.

${ }^{8}$ Cf. SCHOPENHAUER, A. WWV II/MVR II, cap. XLVIII, p. 339.

${ }^{9}$ Idem, cap. XLVIII, p. 339.

As vias de negação da vontade em Schopenhauer 
indivíduo, mas faz do sofrimento alheio o do próprio agente, que é impelido a ajudar. 0 caridoso, além de respeitar os demais, participa diretamente do sofrimento alheio, tendo como objetivo ajudar o outro "para tirá-lo de sua necessidade e dificuldade e por querer sabê-lo livre de seu sofrimento - e nada além disso!"10. Ambos, justo e caridoso, mostram que não estão completamente envoltos pelo modo de conhecimento ordinário, e sim, que conseguem enxergar os outros como manifestações da mesma essência que a sua. 0 filósofo afirma que "ser curado dessa ilusão e engano de Maia e praticar obras de amor são uma única e mesma coisa. Estas últimas obras, entretanto, são sintomas inevitáveis e infalíveis daquele conhecimento"11. 0 acesso ao conhecimento que transpassa o princípio de individuação se traduz em atos determinados pela intensidade dessa intuição.

As virtudes morais são expostas, no capítulo XLVIII de MVR II, como meios de promover a negação da vontade por levarem o compassivo a assumir não apenas os próprios sofrimentos, mas também os alheios, trazendo para si uma carga de sacrifícios muito maior do que a que lhe foi imposta pelo curso de sua vida individual. E há quem considere o ascetismo supérfluo quando as virtudes morais já produzem constantes privações e sofrimentos.

Agora, já que, de acordo com isto, a pobreza, as privações e os sofrimentos específicos de vários tipos são produzidos pelo exercício mais completo de virtudes morais, o ascetismo no sentido mais restrito, a desistência de todos os bens, a busca deliberada pelo desagradável e repugnante, a autotortura, o jejum, a roupa de peles, a mortificação da carne, tudo isso é rejeitado por muitos como supérfluos, e talvez com razão. A justiça em si é a roupa de peles que faz com que o sofrimento de seu proprietário seja constante, e a filantropia que dá ao outro o que nos é necessário, é como um constante jejum ${ }^{12}$.

O justo deixa de afirmar integralmente sua vontade para que o direito do outro seja preservado, o caridoso se priva de certo conforto para suprir as necessidades alheias. Eles se afastaram do egoísmo quando deixaram de sobrepor seu bem-estar ao dos demais indivíduos. É provável que não fossem perturbados por determinadas privações se fossem conduzidos pelo egoísmo. Como são compassivos, abraçam as

10 SCHOPENHAUER, A. M /M, § 18, p. 161.

11 SCHOPENHAUER, A. WWV I/MVR I, § 66, p. 474.

12 SCHOPENHAUER, A. WWV II/MVR II, cap. XLVIII, p. 340.

As vias de negação da vontade em Schopenhauer 
privações e sofrimentos consequentes de quando se coloca as necessidades alheias acima do próprio conforto.

A ascese é definida por Schopenhauer como a "quebra PROPOSITAL da Vontade pela recusa do agradável e a procura do desagradável, mediante o modo de vida penitente voluntariamente escolhido e a autocastidade, tendo em vista a mortificação contínua da Vontade"13. Podemos perceber certa semelhança entre as ações compassivas e a ascese: ambas implicam privações e sofrimentos voluntários. Mas haveria distinções significativas no fim dessas ações: na compaixão, essas privações e sofrimentos ocorrem porque o compassivo se sacrifica para aliviar o sofrimento de outros indivíduos; na ascese, elas ocorrem como meios para manter o estado de resignação. As ações compassivas são direcionadas a outrem; as do asceta, ao próprio sujeito. Enquanto o justo nega seus desejos para garantir que os dos outros possam ser afirmados, ou o caridoso supre as necessidades de outras pessoas, o asceta nega a vontade em seu corpo sem visar a afirmação de outrem, tendo como único objetivo a mortificação ${ }^{14}$.

\section{A transição da virtude à ascese: a primeira via para a negação da vontade}

"São as ações morais que permitem a passagem da virtude para a negação do querer-viver, e elas constituem o ponto de ligação entre a moral e a resignação total"15, afirma Cacciola em Schopenhauer e a questão do dogmatismo. A compaixão tem como base o conhecimento da unidade de todos os seres, a mesma condição necessária para que a vontade se vire e passe a se negar. Essa passagem da virtude à ascese não acontece de modo necessário, ela pode acontecer ou não. Não há como deliberar ou induzir o estado de negação da vontade, ele ocorre subitamente. Essa transição é comparada ao que os cristãos chamam de renascimento e o conhecimento que a proporciona é comparado ao efeito da graça ${ }^{16}$. Não há explicação racional para a transição de um estado para o outro, essa passagem ocorre de forma "misteriosa", já que independe de causalidade.

13 SCHOPENHAUER, A. WWV I/MVR I, § 68, p. 496.

14 É possível tomar a pobreza como um exemplo de distinção entre ação compassiva e ascética, a primeira tendo em vista o alívio do sofrimento alheio e a segunda, vista como um fim em si mesma. Nas palavras do filósofo, "a ascese também se mostra na pobreza voluntária e intencional, nascida não somente per accidens, quando a propriedade é doada para aliviar o sofrimento alheio, mas já como um fim em si mesma [...]" (SCHOPENHAUER, A. WWV I/MVR I, § 68, p. 484).

15 CACCIOLA, M. L. Schopenhauer e a questão do dogmatismo, p. 159.

${ }^{16}$ Cf. SCHOPENHAUER, A. WWV I/MVR I, § 70, p. 511. 
Existe um limite para as ações compassivas que quando é ultrapassado torna-se ascese. A compaixão pode atingir um determinado grau e ali se estabilizar. 0 compassivo pode aceitar privações, sofrer e até mesmo doar todos os seus bens em favor de outras pessoas, mas enquanto age com o objetivo de beneficiar outrem continua sendo um compassivo. A negação surge com a supressão do princípio de individuação e a viragem da vontade contra si mesma. 0 asceta reconhece a essência volitiva do mundo em todos os fenômenos. Dessa intuição ele percebe que a vida é constituída por inúmeros sofrimentos, pausados por momentos de alívio, e deixa de participar desse ciclo. Ele toma para si todos os sofrimentos possíveis e não apenas os que estão presentes. Após conhecer e repudiar a essência do mundo da qual seu corpo é uma expressão, adota exercícios ascéticos visando à mortificação da vontade presente em seu corpo, pois sabe que tentar satisfazer seus desejos é vão e que esses desejos retornarão ou serão substituídos por outros, impedindo uma satisfação permanente.

0 asceta, por possuir uma conduta diferente da conduta ordinária, mostra que conseguiu superar completamente a ilusão da individuação e atingir o conhecimento da essência do mundo. As atitudes do asceta não estão direcionadas para beneficiar outrem, como ocorre com o compassivo, mas se caracterizam pelo direcionamento ao próprio agente, para mortificar a si mesmo. É para obstar o próprio querer que ele se anula e não para diminuir o sofrimento de outrem. Conhecer o sofrimento, que para o compassivo é um motivo que impele à ação, para o asceta é um quietivo que conduz à resignação. Nas palavras do filósofo:

O acontecimento, pelo qual isso se anuncia, é a transição da virtude à ASCESE. Por outros termos, não mais adianta amar os outros como a si mesmo, por eles fazer tanto como se fosse por si, mas nasce uma repulsa pela essência da qual seu fenômeno é uma expressão, vale dizer, uma repulsa pela Vontade de vida, núcleo e essência de um mundo reconhecido como povoado de penúrias ${ }^{17}$.

Quando ocorre a supressão do conhecimento submetido ao princípio de individuação, o sujeito deixa de fazer diferença entre si e os demais, reconhecendo seu próprio íntimo em todos os seres, as dores de todo o mundo passam a ser suas e nenhum sofrimento lhe parece estranho. 0 conhecimento do todo e da essência do mundo torna-

17 SCHOPENHAUER, A. WWV I/MVR I, § 68, p. 482. 
se um quietivo para a vontade. 0 homem com esse conhecimento passa a ser indiferente ao que antes se apresentaria como motivos para seu querer. Porém, a negação da vontade pela via do conhecimento é para poucos. Somente para os "eleitos" conhecer o sofrimento alheio faz efeito e conduz à resignação e, para Schopenhauer, são raros os sujeitos que chegam à negação dessa forma.

$\mathrm{Na}$ maioria dos homens a ascese chega por meio do sofrimento sentido, que constitui um segundo caminho ( $\delta \varepsilon v ́ \tau \varepsilon \rho o \varsigma \pi \lambda o v \varsigma^{18}$ ) para a negação da vontade. É o sofrimento pessoal intenso e, na maioria dos casos, a proximidade da morte, que pode levar o homem comum à completa resignação. No $\S 68$ de MVR I, o filósofo afirma o seguinte:

Sim, podemos assumir que a maioria dos homens só chega ao mencionado fim por esta via; logo, que é o sofrimento pessoalmente sentido, não o meramente conhecido, o que com mais frequência produz a completa resignação, e na maioria das vezes a proximidade da morte. Em realidade, só entre alguns poucos o simples conhecimento que vê através do principium individuationis é suficiente para conduzir à negação da Vontade, primeiro ao produzir a mais perfeita bondade na disposição de caráter e o amor universal à humanidade, por fim ao permitir reconhecer em todo sofrimento do mundo o próprio sofrimento ${ }^{19}$.

Na citação acima, Schopenhauer fala em "perfeita bondade na disposição de caráter", em outras passagens fala em "belas almas" e "eleitos". Com isso, parece sugerir que essas pessoas possuem algum traço de caráter que as distingue das demais e faz com que sejam consideradas santas. 0 curso de suas vidas mostra que elas não foram egoístas ou más e mudaram em determinado momento. Elas são sensíveis ao sofrimento alheio e agem a fim de diminuir esse sofrimento. Demonstraram que eram pessoas compassivas e como resultado de uma compaixão tão elevada que faz com que o agente sofra e tenha tantas privações para cumprir seu objetivo de melhorar a vida de outrem pode ter surgido a renúncia total. Schopenhauer afirma no capítulo XLVIII de MVR II que "essas virtudes morais são um meio de promover a autonegação, e, portanto, de negar a Vontade de viver" 20 . No caso desses santos, as virtudes morais se elevaram a tal grau que a ascese pode ser decorrente dos sacrifícios realizados em prol dos outros. Se a ascese é

\footnotetext{
18 Expressão usada por Platão no Político e no Fédon, que tem origem na linguagem da navegação.

19 SCHOPENHAUER, A. WWV I/MVR I, § 68, p. 497.

${ }^{20}$ SCHOPENHAUER, A. WWV II/MVR II, cap. XLVIII, p. 339.

As vias de negação da vontade em Schopenhauer
} 
uma quebra proposital da vontade por meio de constantes privações e sofrimentos, o compassivo está muito próximo dela quando assume os sofrimentos que caberiam aos outros e, com isso, torna sua existência muito mais pesada do que seria em seu curso normal.

Quem é inspirado por essa virtude reconheceu o seu próprio ser no outro. Nesse caminho, ele agora identifica sua própria sorte com a que corresponde à humanidade inteira, mas esta escolha é muito difícil, pois implica em labuta, sofrimento e morte. Portanto, aquele que renuncia a toda vantagem acidental, deseja para si mesmo um fardo não muito diferente do que possui a humanidade em geral, não pode mais querer que isto perdure. Isso abre caminho para a renúncia universal, consequentemente, a negação da vontade ocorrerá 21 .

É importante destacar que, como sabemos, o compassivo nem sempre se torna asceta. A transição da virtude à ascese é um fenômeno raríssimo. Os atos com valor moral podem ser meios de fomentar a negação da vontade, mas daí não se deve entender que a ascese decorrerá necessariamente no homem de caráter compassivo ou que somente ele poderá atingir o estado de resignação total. No final do §68 de MVR I, Schopenhauer fala sobre a diferença ética dos caracteres para a negação da vontade. Ele afirma que "a pessoa má está infinitamente distante de atingir o conhecimento a partir do qual provém a negação da Vontade"22, pois está profundamente vinculada ao princípio de individuação. Também em PP, a distância da salvação daqueles que praticam ações injustas e vis é mencionada pelo filósofo:

Ações injustas ou vis são, em vista daquele que as pratica, sinal do vigor de sua afirmação da vontade de viver e portanto da distância em que ele está da verdadeira salvação, a negação da vontade, em suma, a redenção do mundo, e assim também do longo aprendizado do conhecimento e do sofrimento, que ainda há que suportar, até alcançá-la. Todavia, com respeito àquele que sofre por causa destas ações, estas, embora sejam fisicamente um mal, são metafisicamente um bem e no fundo uma benfeitoria, já que contribuem para conduzi-lo à verdadeira salvação 23 .

Como o compassivo é sensível ao sofrimento alheio, parece estar mais próximo da

${ }^{21}$ SCHOPENHAUER, A. WWV II/MVR II, cap. XLVIII, p. 339-340.

22 SCHOPENHAUER, A. WWV I/MVR I, § 68, p. 503.

23 SCHOPENHAUER, A. P/P, § 171, p. 183-184, grifo meu. 
negação pela primeira via, quando apenas conhecer o sofrimento já conduz à resignação, enquanto para um egoísta ou maldoso o sofrimento no próprio corpo apresenta-se, via de regra, mais eficaz para que se chegue à experiência de negação da vontade. 0 compassivo está mais próximo da negação pela primeira via, mas não é impossível que em determinado momento uma pessoa com outro tipo de caráter esteja sensível a um sofrimento ocorrido a outrem, já que os tipos de caracteres são determinados pela predominância e não por unanimidade.

A compaixão situa-se entre a afirmação e a negação da vontade. Ela se assemelha à afirmação porque é uma relação entre motivo e caráter que faz surgir o ato compassivo. A representação do outro e de seu sofrimento atua como motivo em um caráter compassivo. Por outro lado, assemelha-se à negação da vontade por ter como fundamento metafísico o conhecimento intuitivo da unidade da essência do mundo. Da mesma raiz que brota a afirmação da vontade, brotam a injustiça, a maldade, o ódio, o egoísmo, e todas as ações que visam somente o bem-estar do próprio agente, pois cada um se considera o centro do mundo e completamente diferente dos demais; assim como a justiça espontânea, a caridade, a unidade de todos os seres e a negação da vontade também brotam da mesma raiz; essas duas raízes encontram-se em polos opostos. "Se este for o caso, então a ação virtuosa é uma passagem momentânea [momentaner Durchgang] para um estado, que quando se estabelece de modo permanente é a negação da Vontade de viver"24.

\section{A segunda via para a negação da vontade}

São os atos compassivos que abrem caminho e fomentam a negação da vontade, que só ocorrerá com a viragem da vontade a partir da supressão do conhecimento submetido ao princípio de individuação. Porém, são raros os casos em que a ascese se dá por essa via. Se essa fosse a única possibilidade, um santo seria algo ainda mais raro do que é. A segunda via para a negação ( $\delta \varepsilon v ́ \tau \varepsilon \rho o \varsigma \pi \lambda o v \varsigma)$, o sofrimento radicalmente vivido, abre a possibilidade para que mais indivíduos se tornem ascetas. 0 filósofo afirma que

Na maioria dos casos a Vontade tem de ser quebrada pelo mais intenso sofrimento pessoal, antes de a sua autonegação entrar em cena. Então 
vemos o homem, trazido às raias do desespero após haver sofrido todos os graus de uma aflição crescente sob os reveses mais violentos, subitamente retirar-se em si mesmo, reconhecer a si e ao mundo, mudar todo o seu ser, elevar-se por sobre sua pessoa e todo sofrimento, como se fora purificado e santificado por este, em paz inabalável, em beatitude e sublimidade, livremente renunciando a tudo o que antes queria com a maior veemência, e receber alegremente a morte. Eis aí a mirada argêntea que subitamente entra em cena a partir da flama purificada do sofrimento; a mirada da negação da Vontade, ou seja, da redenção. Mesmo aqueles que eram pessoas más, vemo-los às vezes purificados até este grau mediante a mais profunda dor: tornam-se outros, completamente convertidos ${ }^{25}$.

Em tais pessoas a transição para a ascese teria acontecido por meio de um sofrimento intenso, capaz de efetuar uma supressão do caráter do indivíduo. Não existe mudança parcial, tudo o que era relativo ao indivíduo desaparece e dá lugar a um novo sujeito. Sem o caminho aberto pelo sofrimento sentido pelo próprio sujeito, a negação não seria possível para aqueles que em momento algum se sensibilizaram com o sofrimento alheio. Os sofrimentos, e junto com eles a possibilidade de conversão, "estão no caminho dos pecadores"26.

O sofrimento é, em potência, uma "força santificadora"27. Porém, ele só leva o sujeito à ascese quando se torna "simples e puro conhecer"28. Nem sempre o sofrimento se torna conhecimento e nem todos os que experimentam um grande sofrimento se tornarão ascetas. O sujeito precisaria se dar conta de que sua vida consiste em uma sucessão de sofrimentos, interrompidos por breves momentos de tranquilidade. A percepção de que o sofrimento que sente também é sentido em todos os demais seres leva-o a apreender a essência do mundo e negá-la. O conhecimento do sofrimento individual não é suficiente para a negação da vontade, sendo necessário conhecer o sofrimento inerente à vida. 0 sofrimento individual seria apenas o ponto de partida para o conhecimento geral. A vontade só é quebrada pelo sofrimento quando é reconhecida como um erro, quando todo esforço que ela impele é reconhecido como vão e esse conhecimento a torna repulsiva para o sujeito. É o conhecimento do conflito interno da vontade e de sua nulidade essencial que atua como quietivo e leva à resignação. 0 conhecimento é que torna possível a negação da vontade, seja por meio da visão e

${ }^{25}$ SCHOPENHAUER, A. WWV I/MVR I, § 68, p. 497.

${ }^{26}$ SCHOPENHAUER, A. WWV II/MVR II, cap. XLIX, p. 380.

27 SCHOPENHAUER, A. WWV I/MVR I, § 68, p. 501.

28 Idem, § 68, p. 502.

As vias de negação da vontade em Schopenhauer 
apropriação do sofrimento alheio, seja por meio do sofrimento radicalmente vivido ${ }^{29}$.

A conversão proporcionada por meio do sofrimento nem sempre é definitiva, é possível que na ausência do sofrimento a individualidade retorne. Schopenhauer cita exemplos de pessoas que foram convertidas definitivamente, como Raimund Lullius e Abbe de Rancé; outras que, passada a ocasião de seu sofrimento, voltaram ao seu antigo caráter, como ocorreu com Benvenuto Cellini ${ }^{30}$; e, ainda, outras que experimentaram um grande sofrimento e não foram em nada afetadas, caso do Cardeal de Beaufort ${ }^{31}$. "Em realidade, para cada sofrimento é possível pensar em uma vontade que o supera em veemência, sendo esta ['mudança transcendental'] então inconquistável por aquele [indivíduo que sofre]"32. Por isso, nem todos os que experimentam um grande sofrimento se converterão, pois existem desejos que se sobrepõem ao sofrimento, impedindo o indivíduo de alcançar o conhecimento da nulidade de todo esforço.

$\mathrm{Na}$ vida real vemos pessoas infelizes, que tiveram de amargar grande medida de sofrimento, irem de encontro a uma morte vergonhosa, violenta e amiúde atroz no cadafalso, em completo vigor mental, e também amiúde as vemos convertidas dessa maneira. Não devemos de modo algum assumir que entre seu caráter e o da maioria dos homens exista uma grande diferença, como parece sugerir sua sorte, mas temos que atribuir esta última em grande parte às circunstâncias: são entretanto culpadas e em grau considerável más. Contudo, vemos muitos dentre elas convertidas da maneira mencionada, após a completa perda de esperança. Mostram agora, de fato, bondade e pureza na disposição de caráter, aversão verdadeira pela prática de qualquer ato minimamente mau ou destituído de caridade ${ }^{33}$.

Entre essas pessoas não há, necessariamente, uma diferença de caráter. As diferenças de caráter nunca entram em cena durante a negação da vontade, elas pertencem à sua afirmação. Em outros termos, tudo que é relativo ao indivíduo diz respeito à esfera da afirmação da vontade e é suprimido caso a negação aconteça. A conversão pelo sofrimento ocorre de maneira aleatória, não havendo uma relação de causa e efeito. Nesse sentido, é importante destacar que nem sempre a vontade se torna

\footnotetext{
${ }^{29}$ Cf. Idem, § 68, p. 503.

${ }^{30}$ Benvenuto Cellini converteu-se pela primeira vez na prisão e outra vez quando foi acometido por uma grave doença, mas recaía em seu antigo estado quando o sofrimento desaparecia.

31 Personagem da obra Henrique VI, de Shakespeare, que morre desesperado, pois o sofrimento e a proximidade da morte não foram suficientes para quebrar sua vontade veemente, que chegava até o extremo da crueldade.

32 SCHOPENHAUER, A. WWV I/MVR I, § 68, p. 500.

33 Idem, p. 498.

As vias de negação da vontade em Schopenhauer
} 
repugnante para quem sofre.

No $§ 68$ de MVR I, Schopenhauer expõe a conversão de Raimund Lullius, “que, finalmente convidado ao quarto da bela dama por quem a tanto tempo se enamorou, lá chegando, e, já antegozando a satisfação de todos os seus desejos, de repente a vê abrir o corselete e mostrar-lhe o peito corroído por um terrível câncer"34. Tal experiência apresentou-se como ocasião de sua conversão, depois da qual ele abandona a corte de Mallorca e vai penitenciar no deserto. No capítulo XLVIII de MVR II, é narrada a conversão do Abbe de Rancé, que, ao visitar Madame de Montbazon, mulher com quem vivia uma relação passional, entrou em seu quarto e esbarrou com o pé em sua cabeça, separada do tronco, e a partir disso teve seu comportamento completamente modificado. Não havia indícios de que ele se tornaria um asceta antes do fato mencionado. Durante sua juventude, se dedicou ao prazer e à diversão, mas após experimentar esse grande sofrimento, entrou e reformou a ordem dos trapistas, retomando o rigor e elevado grau de renúncia que essa ordem já havia perdido ${ }^{35}$. Esses são dois dos casos em que, aos olhos de Schopenhauer, a negação da vontade ocorreu por meio de um sofrimento intenso. A supressão da individualidade aconteceu com ambos quando o sofrimento se apresentou e conseguiram manter-se nesse estado de negação até o final de suas vidas.

Schopenhauer afirma que "o sofrimento é o processo de purificação que, na maioria dos casos, já basta ao homem para a sua santificação, em outras palavras, liberta-o do caminho do erro a que o conduziu a Vontade de viver" 36 . De acordo com o filósofo, em nós há um erro inato: o de pensar que vivemos para sermos felizes, o que se passa na medida em que concebemos o conceito de felicidade como satisfação sucessiva de todo o nosso querer ${ }^{37}$. Ao longo de nossas vidas nos deparamos com dores, lutas e frustrações que farão com que esse propósito pareça contraditório para quem persiste no erro. Em suas palavras:

O destino e o curso das coisas, no entanto, cuidam de nós melhor do que nós mesmos, uma vez que frustram por todos os lados os nossos arranjos para uma existência utópica, cuja loucura é visível

\footnotetext{
34 Idem, p. 499-500.

35 Cf. SCHOPENHAUER, A. WWV II/MVR II, cap. XLVIII, p. 369.

36 SCHOPENHAUER, A. WWV II/MVR II, cap. XLIX, p. 377.

37 Cf. Idem, cap. XLIX, p. 375.

As vias de negação da vontade em Schopenhauer
} 
o suficiente pela sua brevidade, incerteza, nulidade, terminando, por fim, em morte amarga 38 .

Quem continua a esperar que a vida possa proporcionar alguma felicidade duradoura se lamentará quando, pela experiência, verificar o quanto é difícil a satisfação de seus desejos e como ela é sempre menor que aquela felicidade vislumbrada a distância. As metas estabelecidas ao longo da vida, vistas de longe, fazem parecer que quando alcançadas proporcionarão uma grande satisfação e repouso. Porém, quando finalmente chega-se ao objetivo, vê-se que pouco do que era esperado e foi prometido pela miragem distante foi efetivamente cumprido. Dores, doenças e tristezas costumam superar as expectativas e estão aí para alertar e despertar os indivíduos do erro, para mostrar que não é a felicidade o propósito da existência. Mas, ao lutar contra o sofrimento, buscando prazer e segurança, o conhecimento da nulidade de todo esforço fica mais distante. É por isso que na velhice as pessoas possuem um semblante de frustração; muitas já perceberam o quanto a afirmação da vontade promete o que não pode cumprir, o quanto a satisfação dos desejos é insuficiente para proporcionar a tranquilidade e alegria prometida. A vida possui um caráter estranho e ambíguo com dois propósitos opostos: o propósito individual está dirigido à felicidade quimérica, um sonho de uma existência feliz; o outro propósito é o do destino, que nos direciona à destruição dessa ilusão de que podemos desfrutar uma existência agradável e nos desata dos laços do mundo ${ }^{39}$.

Sentimos as dores, os infortúnios e o medo. No entanto, os prazeres, a saúde, a tranquilidade e a segurança não são sentidos. Eles podem ser percebidos apenas quando os comparamos com momentos infelizes, reflexivamente, e não no momento em que estão presentes. Isso mostra, como sabemos, que a dor é de natureza positiva, enquanto toda satisfação é de natureza negativa. Nossa capacidade de perceber os prazeres diminui na medida em que aumentam. Eles deixam de ser vistos como prazer porque nos acostumamos. Dessa mesma forma, nossa suscetibilidade para o sofrimento aumenta, pois sentimos dolorosamente a privação daquilo que estamos acostumados. Enquanto estamos nos divertindo não sentimos o tempo passar, mas quando fazemos algo doloroso ou entediante sentimos passar lentamente, o que sugere que a vida é mais agradável quando menos a sentimos. Por isso, seria melhor não existir.

38 Idem, cap. XLIX, p. 381.

${ }^{39}$ Cf. Idem, cap. XLIX, p.380-381.

As vias de negação da vontade em Schopenhauer 
O curso da vida nos encaminha para a velhice e para a morte, sentenças de condenação da própria natureza que levam à percepção de que todo o esforço despendido durante a vida trouxe apenas satisfações provisórias, que só foram notadas após um certo distanciamento, pela lembrança dos momentos de tranquilidade em contraste com o sofrimento presente. Só percebemos que tivemos saúde quando a doença se apresenta, só lembramos da liberdade quando não a temos mais. Os infortúnios nos fornecem material para comparação com o que já vivemos e, assim, chegamos à conclusão de que o prazer e a tranquilidade já estiveram presentes.

Diante da consciência da morte como destino inevitável, de que toda a agitação da vida e empenho para atingir determinadas metas não podem nos proporcionar uma satisfação duradoura, Schopenhauer aponta a negação da vontade como a salvação para a nossa existência desprovida de finalidade. A ilusão que faz com que o indivíduo persiga uma felicidade quimérica cede seu lugar à resignação, a única possibilidade de redenção. A tentativa de amenizar os sofrimentos inerentes à existência adia, ou até mesmo torna inviável a verdadeira salvação, já que desperdiça a "força santificadora" do sofrimento. Schopenhauer afirma que

\footnotetext{
O estoicismo da disposição, que oferece consolo diante do destino, e certamente uma boa couraça contra os sofrimentos da vida, é útil para melhor suportar o presente: ele se põe, porém, contra a verdadeira salvação, pois ele endurece o coração. Como poderia este ser melhorar por meio dos sofrimentos, se, envolto numa grossa casca pétrea, não os percebe ${ }^{40}$ ?
}

A insensibilidade ao sofrimento tanto de outrem quanto o próprio é favorável para um curso de vida mais agradável, mas fecha o caminho da redenção. Qualquer meio de alívio ao sofrimento presente é um adiamento da salvação. Sem o sofrimento alheio, ações compassivas não são suscitadas nos indivíduos com tal disposição e na falta do sofrimento sentido pelo próprio indivíduo o conhecimento que atua como quietivo do querer não pode surgir. Portanto, a ausência de sofrimento torna impossível a negação da vontade tanto pela primeira, quanto pela segunda via.

\section{Considerações finais}

40 SCHOPENHAUER, A. P/P, § 170, p. 183.

As vias de negação da vontade em Schopenhauer 
Pelo o que foi considerado, o pensamento schopenhaueriano permite afirmarmos que o indivíduo compassivo estaria mais próximo da negação pela primeira via por ser sensível ao sofrimento alheio, já que, por meio desse sofrimento, pode chegar ao conhecimento que torna possível a viragem da vontade. Na segunda via, essa transição da afirmação para a negação se dá por meio de um sofrimento radical sentido pelo próprio sujeito e qualquer tipo de caráter possuiria as mesmas condições de atingir a negação por essa via. Ambas as vias de negação, entretanto, têm como base o conhecimento da essência volitiva do mundo e do sofrimento inerente à existência.

Depois de atingida a negação da vontade, a permanência nesse estado não é automática, mas requer um esforço contínuo, pois o corpo, como objetivação da vontade, estará sempre atrelado aos desejos. Cabe ao asceta conduzir sua vida de uma forma que contrarie a vontade que insiste em se manifestar enquanto o corpo sobrevive. Renúncias e autopenitências constituem o cotidiano do asceta. Castidade, pobreza, jejum e autoflagelo são práticas adotadas pelas pessoas para que permaneçam na paz já experimentada quando a vontade se virou contra si mesma. A morte pode surgir como consequência das práticas citadas acima, mesmo que um asceta não possa ser confundido com um suicida. No suicídio o indivíduo quer viver, porém, não encontrou as condições que gostaria e, em um ato de afirmação da vontade, põe fim à sua existência, um fenômeno particular, por repudiar o sofrimento e não a essência volitiva do mundo 41 . O sofrimento sentido pelo suicida não chega ao ponto de levá-lo à negação da vontade porque é interrompido pelo ato volitivo que suprime o corpo ao invés de suprimir o querer. A morte do asceta seria o último estágio da negação da vontade, o apagar da mais fraca chama que ainda se encontrava no sujeito. 0 asceta conhece a essência do mundo e recusa seus prazeres, até mesmo os necessários à sua sobrevivência. A morte, como resultado da ascese, ocorre quando se renuncia à autoconservação, o que há de mais básico na vida, a ponto de não restar nesse tipo de sujeito nem mesmo a vontade necessária para ingerir alimentos. Nesse caso, o asceta deixaria de viver porque já teria deixado de querer.

\section{Referências bibliográficas}

41 SCHOPENHAUER, A. WWV I/MVR I, § 69, p. 504. 
CACCIOLA, Maria Lúcia Mello e Oliveira. Schopenhauer e a questão do dogmatismo. São Paulo: Edusp, 1994.

SCHOPENHAUER, Arthur. O mundo como vontade e como representação. Tomo I. Tradução de Jair Barboza. São Paulo: Editora UNESP, 2005.

O mundo como vontade e representação. Tomo II. Vol. 1. Tradução de Eduardo Ribeiro da Fonseca. Curitiba: Ed. UFPR, 2014.

. Sobre o fundamento da moral. Tradução de Maria Lúcia Mello Oliveira Cacciola. São Paulo: Martins Fontes, 2001.

. Sobre a Ética. Tradução brasileira dos capítulos 8 a 15 de Parerga e Paralipomena. Tomo II. Flamarion Caldeira Ramos. São Paulo: Hedra, 2012.

Recebido: 06/10/16

Received: 10/06/16

Aprovado: 21/11/16

Approved: 11/21/16 